\title{
GENERATYWNOŚĆ GEJÓW, KTÓRZY UKOŃCZYLI 40. ROK ŻYCIA - AMERYKAŃSKA INSPIRACJA DLA POLSKICH BADAŃ
}

MARIA BIEGAŃSKA

bieganskamaria@gmail.com

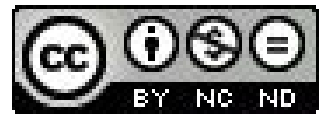

\section{PrZelom POŁOWY ŻYCIA - CZAS Generatywności}

Po ukończeniu czterdziestego roku życia wiele w życiu człowieka się zmienia - mówi się o „przełomie życia”, czy kryzysie, który dotyka osoby w tym wieku. Jest to początek kolejnego etapu rozwojowego, rozwiązywanie kolejnego konfliktu. Miarą sukcesu w tym okresie jest umiejętne zintegrowanie przeciwieństw: młodość - starość i pogodzenie się $\mathrm{z} \mathrm{nimi}^{1}$. W związku z kulturowymi przemianami starość raczej nie jest już kojarzona z mądrością i doświadczeniem, ale czymś wstydliwym, co spycha człowieka na margines życia społecznego.

Z pewnością taka wizja starości nie sprzyja pozytywnemu rozwiązaniu konfliktu, a przede wszystkim przygotowaniu się do starości. Co zatem może pomóc? Integracja obszarów refleksji związanych z młodością i starości jest możliwa, gdy czterdziestolatek pogodzi się z upływającym czasem, będzie miał poczucie, że jego życie jest sensowne. Często pocieszeniem i wielką wartością w przełamaniu kryzysu jest świadomość, że ma się coś do przekazania młodszemu pokoleniu ${ }^{2}$.Troska o młodych $\mathrm{i}$ „ppotrzeba bycia potrzebnym” to jedne z podstawowych elementów składających się na generatywność.

\section{Generatywność w UJęCiU E. ERIKSONA}

W obszarze psychologii koncepcja generatywności pojawiła się po raz pierwszy za sprawą E. Eriksona w połowie lat pięćdziesiątych ubiegłego wieku, który określił generatywność jako jedną z cech charakteryzujących okres średniej dorosłoścỉ. Młodzi dorośli bowiem skupiają się na budowaniu swej tożsamości oraz intymnych więzi z innymi. Późna dorosłość sprzyja przede wszystkim integracji ego oraz bilansowaniu życia. Zaś okres średniej dorosłości jest niejako pomostem między tymi dwoma okresami. Człowiek nie jest już „młody”, jednak nie jest jeszcze „stary”. Zdaniem Eriksona, to właśnie w tym czasie dorośli powinni i często stają się opiekunami, przewodnikami oraz wnoszą wiele w rozwój przyszłych pokoleń. Zdaniem Eriksona istnieje związek między przejawianiem generatywności na co dzień, w dobroci i trosce, a zdrowiem psychicznym i dobrym samopoczuciem. Generatywność wg Eriksona jest ze wszech miar egalitarna - każdy dorosły może być generatywny.

\section{Koncepcja generatywności D. Mc Adamsa}

Dopełnieniem Eriksonowskiej koncepcji generatywności stały się tezy wywiedzione z badań przez Mc Adamsa i jego współpracowników ${ }^{4}$ Stworzyli oni integracyjny model generatywności, w którym podkreślaja, że może się ona przejawiać na wielu poziomach i wymiarach.

\footnotetext{
P. Oleś, Psychologia przełomu połowy życia, Lublin 2000, s. 75.

Tamże, s. 76

D. P. Mc Adams, Generativity in midlife, [w:] M. E. Lachman (red.), Handbook of midlife development, New York 2001.

D. P. Mc Adams, E. de St. Aubin, A theory of generativity and it's assessment through self - report, behavioral acts, and narrative themes in autobiography, "Journal of Personality and Social Psychology" 1992, nr 62, s. 1003-1015. D. P. Mc Adams, E. de St. Aubin, R. Logan, Generativity among young, midlife and older adults, "Psychology and Aging" 1993, nr 8, s. 221-230.
} 
Mc Adams, poszerzając koncepcję Eriksona twierdzi, że generatywność to zaangażowanie we wspieranie przyszłych pokoleń poprzez m.in. rodzicielstwo, nauczanie, pełnienie roli liderów i mentorów. Dorośli w okresie średniej dorosłości w sposób szczególny chcą opiekować się innymi, chcą czuć się potrzebni („,potrzeba bycia potrzebnym”) - tego wymaga od nich także społeczeństwo.

Mc Adams uważa, że kluczowe dla generatywności pojęcia to: pragnienia, oczekiwania (kulturowe, społeczne), troska, wiara lub przekonania, zaangażowanie, działanie i narracja. Początek generatywności dają pragnienia, które skłaniają jednostkę do poszukiwania sposobów na to, by stać się niejako „symbolicznie nieśmiertelnym” oraz by troszczyć się i dbać o innych. Obok tych pragnień istnieją także społeczne wymagania, według których jednostki w średnim wieku powinny brać odpowiedzialność za kolejne pokolenie. Zatem źródła generatywności są zarówno zewnętrze, jak i wewnętrzne. Wypływa z nich bezpośrednio troska o przyszłe pokolenie, wyrażająca się między innymi w działaniach na rzecz instytucji wspierających pozytywny rozwój i funkcjonowanie młodych ludzi (szkoły, kościoły, organizacje dobroczynne) oraz troska o dobre międzypokoleniowe relacje. Osoby, które przekroczyły czterdziesty rok życia spostrzegaja bowiem, że mogą dać coś innym, że to być może właściwy moment na "zrewanżowanie się" społeczeństwu, na stanie się dającym, a nie tylko otrzymującym.

Obok pragnień, wymagań i troski istnieje także wiara (czy przekonania), określająca celowość „,inwestowania” w innych. Jest to nawiązanie do Eriksonowskiej „,wiary w ludzkość” (belief in species), czy raczej w "gatunek", którą spostrzegał jako podstawowe wsparcie dla generatywnych zachowań. Owe przekonania mogą wyrażać się np. w wierze w dobroć ludzkości / rodzaju ludzkiego, nadziei na odkupienie (redemption) w przyszłości, optymistycznym patrzeniu na przyszłość własnej rodziny, w wierze w sprawiedliwy świat itd.

Natomiast pesymizm, cynizm i brak nadziei nie sprzyjają generatywności, ponieważ jednostka nie spodziewa się, że zainwestowane siły mogą przynieść w przyszłości pozytywne rezultaty. Wiara i pozytywne przekonania z kolei sprzyjają wysiłkom na rzecz podejmowania generatywnych zobowiązań w postaci wyznaczanych sobie celów czy planów. Jednak należy pamiętać, że nie wszystkie przejawy generatywności są zaplanowane - najbardziej oczywistym przykładem może być nieplanowana ciąża.

Podjęte zobowiązania i wyznaczone $\mathrm{w}$ związku $\mathrm{z}$ nimi cele prowadzą do generatywnych zachowań (actions). Najczęściej za zachowania generatywne uważa się te, które wymagają tworzenia (wprowadzanie innowacji, wydawanie na świat dziecka), podtrzymywania i opieki (zachowywanie religijnych tradycji, wychowywanie dzieci) oraz przekazywania kolejnym pokoleniom tego, co zostało stworzone lub zachowane jako „daru” (uczenie jakichś szczególnych umiejętności, ,oddanie" dorosłego syna lub córki światu).

Ostatnia z siedmiu cech, o których pisze w swej teorii Mc Adams to generatywna narracja. Kiedy dorośli, w oparciu o swoje troski i przekonania podejmują zobowiązania i działania dla dobra kolejnego pokolenia, konstruują osobistą narrację lub opowiadają o swych generatywnych wysiłkach. Generatywność zatem dopełnia autobiograficzną opowieść jednostki. Owe narracje stworzone są dla innych, ale także dla samych siebie. Ludzie opowiadają sobie nawzajem swoje życie, ale opowiadają je także (świadomie lub nieświadomie) samym sobie - by nadać życiu, które wioda, sens. Mc Adams w tym punkcie teorii generatywności łączy ją ze swoją koncepcją narracji. Jej podstawowym założeniem jest to, że współcześni dorośli ludzie wiodą swoje życie z poczuciem jedności i celowości dzięki tworzeniu i internalizacji autonarracji. Składają się na nie m.in. sceny, postacie, fabuła, tematy. 
Teoria ta jest powszechnie znana i opisywana szeroko w polskiej literaturze psychologicznej jednak niezwykle rzadko wspomina się o jej nierozerwalnym połączeniu z ideą generatywności ${ }^{5}$. Sam Mc Adams natomiast pisze, że narracje na temat życia ewoluują i generatywność z czasem staje się ich centralnym motywem, co najpełniej wyraża się w okresie średniej dorosłoścí. Narracje określaja, w jaki sposób jednostka zamierza pozostawić po sobie pozytywne dziedzictwo dla przyszłych pokoleń. Jako taka, generatywna narracja (a może raczej: „,narracja o generatywności”) ma zapewnić jednostce potencjalnie satysfakcjonujące „zakończenie” jej historii życia.

Mc Adams jednak, w przeciwieństwie do Eriksona, nie spostrzega generatywności jako pojęcia związanego z jednym tylko etapem rozwojowym (stadium 7, kryzys generatywność - stagnacja). Na podstawie licznych badań, także własnych Mc Adams skłania się do postrzegania generatywności jako cechy, która towarzyszy człowiekowi przez całe życie, a niektóre jej aspekty nasilają się w okresie średniej dorosłości. W opisie rozwoju człowieka Mc Adams odchodzi od rozpatrywania go w kategoriach odrębnych stadiów rozwojowych, które u każdego następują w takiej samej kolejności. Mc Adams kładzie nacisk na jednostkowość i indywidualizm doświadczeń i przeżyć, a także na badanie różnych wpływów, również tych społecznych, które działają na jednostkę i określa je mianem kulturowych oczekiwań. Dotyczą one podejmowania generatywnych ról w trakcie życia, takich jak na przykład rodzicielstwo (nacisk społeczny na realizowanie tego zadania obejmuje okres od około 30. do 40. roku życia jednostki). Jak pisze Mc Adams, generatywność odnosi się do tworzenia nowych form, które pozostaną po jednostce, będą niejako „przedłużeniem jej życia”, zatem odnosi się do przyszłości. $Z$ drugiej strony jednak także do przeszłości, bowiem kładzie nacisk na zachowanie i przekazanie tego, co cenne w danym społecznym kontekście, kolejnym pokoleniom. Generatywność łączy zatem czas przeszły i przyszły. Jednak to połączenie, jak pisze Mc Adams, nie jest pozbawione napięcia, szczególnie w dzisiejszym społeczeństwie, w którym ściera się tradycja i postęp.

Oprócz zagadnienia czasu, istotne dla rozpatrywania generatywności są także role, które podejmują jednostki - dzięki nim również może wyrażać się generatywność. Podkreśla się wyraźnie ich wielość i zróżnicowanie w ciągu życia. Generatywność może także „przenosić się" zjednej roli na drugą, w zależności od wymagań społecznych. Z pojęciem generatywności wiążą się często także bliskie, długoterminowe związki. Złożoność ról i związków interpersonalnych, które tworzą społeczne relacje wpływają bezpośrednio na jakość, siłę i znaczenie osobistej generatywności. Zatem by móc mówić o generatywności należy brać pod uwagę także społeczny kontekst życia jednostki.

W przypadku badań dotyczących gejów (oraz osób homoseksualnych w ogóle), wydaje się on być szczególnie ważny. Znajdują się oni, jak się wydaje, pod większym naciskiem społecznym - ich życie jest niejako definiowane przez nakazy i oczekiwania społeczne. Wydaje się również, że trudniej jest homoseksualnych mężczyzn (i nie tylko ich) „dopasować” do stadialnego schematu rozwoju człowieka.

GENERATYWNOŚĆ, COMING OUT' ${ }^{7}$, DYSKRYMINACJA - BADANIA AMERYKAŃSKIE

Zdaniem amerykańskich badaczy generatywności wśród gejów, ich rozwój zdaje się być znacznie mniej uporządkowany, niż zakładają teorie rozwojowe oparte na stadiach i zawsze

\footnotetext{
$5 \quad$ P. Oleś, Wprowadzenie do psychologii osobowości, Warszawa 2008, s. 344-350.

6 Por. D. P. Mc Adams, A theory..., dz. cyt., s. 414.

Polskie określenie tego zjawiska jako „wyjście z szafy” nie oddaje moim zdaniem jego istoty, zatem konsekwentnie w dalszej części tekstu będzie pojawiać się wyrażenie „coming out”.
} 
ów rozwój należy rozpatrywać biorąc pod uwagę większy społeczny, czy wręcz historyczny, kontekst i wyjątkowe dla danej jednostki wydarzenia, które miały miejsce w jej życiü. Warto zatem w badaniach skłonić się ku „perspektywie biegu życia” (life course perspective), bowiem daje ona możliwość dostrzeżenia bardziej szczegółowego obrazu rozwoju jednostki i jej życia. Autorzy zwracają uwagę, że ów „bieg życia” osób homoseksualnych, w tym gejów, może być inny, niż ten normatywnie przewidywany. W Stanach Zjednoczonych wiele par jednopłciowych ma dzieci lub jest zastępczymi rodzicami, jednak inne decydują się na związek partnerski, ale nie rodzicielstwo. W Polsce, $\mathrm{w}$ świetle prawa, związki jednopłciowe nie istnieja, a prawa do opieki nad dziećmi nie domagają się nawet organizacje zrzeszające homoseksualistów. Zatem rodzą się tu pytania dotyczące roli generatywności w życiu dorosłych gejów, a także jej przejawów. Czy rodzicielstwo to najważniejsza charakterystyka generatywności?

W czasach, kiedy wiele osób, także heteroseksualnych, nie decyduje się na pełnienie roli rodzica, należy ponownie rozważyć nierozerwalność związku generatywności i rodzicielstwa. Cohler, Hostetler i Boxer postuluja, by generatywność rozpatrywać w szerszym kontekście. Nie można bowiem, ich zdaniem, pomijać tego, w jaki sposób oddziałuje społeczna stygmatyzacja i dyskryminacja. Wydaje się przy tym, że mogą one stanowić większy problemem w Polsce dziś, niż w Stanach Zjednoczonych w $1998 \mathrm{r}$.

Generatywność bywa często ograniczana do rodzicielstwa, które jest poza zasięgiem wielu gejów (szczególnie w Polsce). Jednak należy zwrócić uwagę na inne jej przejawy - wielu gejów stara się „,sięgać" ku przyszłym pokoleniom poprzez uczenie, pracę $\mathrm{w}$ organizacjach społecznych itp. Badania nad generatywnością (Cornett i Hudson) wśród bezdzietnych homoseksualistów potwierdziły, że szukają oni innych form ekspresji generatywności, niż rodzicielstwo ${ }^{9}$. Nie można zatem zawężać generatywności tylko do rodzicielstwa, i czynić oba pojęcia równoznacznymi - nie można pomijać złożonej natury generatywności jako przejawu szeroko rozumianej troski o przyszłe pokolenia. Zgodnie z koncepcją Mc Adamsa, rodzicielstwo może prowadzić do realizowania generatywności, jednak nie zawsze jest konieczną ani wystarczającą do niej drogą. Mc Adams sugeruje, że osoby generatywne przejawiają wielkie zaangażowanie i troskę o dobro innych, które wynika z pokonania jakichś szczególnych trudności. Takie zjawisko występuje wśród gejów i lesbijek w średnim wieku, dla których owymi trudnościami były stygmatyzacja i dyskryminacja. Homoseksualiści w średnim wieku, badani pod koniec dwudziestego wieku w USA, w swoim życiu kierowali się tym, by przyszłe pokolenia mogły uniknać cierpienia wynikającego ze stygmatyzacji - wielu aktywistów skupiło się na zmianie praw i obyczajów tak, by sprzyjały równości.

Temat starości i starzenia się gejów podejmują m. in. M. Pope, E. A. Wierzalis, B. Barret oraz M. Ranking ${ }^{10}$. Próbują oni odpowiedzieć na pytanie, jak starzenie się wpływa na ludzkie życie, na samoocenę, intymność i związki. Są to zdaniem autorów uniwersalne pytania, jednak dla starzejących się gejów mogą stanowić swego rodzaju wyzwania. Wiąże się to z tym, że geje mogą być stygmatyzowani ze względu na swoją orientację, na co z kolei nakładają się negatywne stereotypy dotycząca starzenia się.

8 B. Cohler, A. J. Hostetler, A. M. Boxer, Generativity, social context, and lived experience: Narratives of gay men in middle adulthood, [w:] D. P. Mc Adams, E. de St. Aubin (red.), Generativity and adult development: How and why we care for the next generation, Washington 1998.

9 Por. B. Cohler, A. J. Hostetler, A. M. Boxer, Generativity..., dz. cyt., s. 276

10 M. Pope, E. A. Wierzalis, B. Barret, M. Rankin, Sexual and intimacy issues for aging gay men, "Adultspan Journal" 2007, nr 6, s. 68-72. 
Autorzy również zwracają uwagę na coming out jako niezwykle ważne doświadczenie w życiu gejów, podnosząc je wręcz do rangi zadania rozwojowego. Rozumieją je zarówno jako wyzwanie na płaszczyźnie społecznej, jak i osobistej, używając sformułowania „coming out'u przed samym sobą". Takie przyznanie się do bycia gejem przed samym sobą często decyduje o zdrowiu i dobrostanie jednostki. Mc Adams, komentując artykuł P. Hammacka, pisze o kulturowo dostępnych narracjach, wg których geje mogą opowiadać o rodzeniu się ich samoświadomości jako osób homoseksualnych ${ }^{11}$. Najpopularniejszy schemat takiej narracji we współczesnej Ameryce jest następujący: młody chłopiec „wie", że pociagają go osoby tej samej płci, może ignorować te uczucia lub zwalczać je, wreszcie nawet spotykać się z kobietami i angażować się w inne działania, by „stać się" heteroseksualistą. Jednak z czasem akceptuje swoją seksualność i wtedy może dokonać coming out'u. Zatem coming out staje się w tego typu narracjach bardzo mocną metaforą - bohater wychodzi z ukrycia, odkrywa prawdę, którą tak długo ukrywał przed sobą i innymi.

W kwestii dyskryminacji gejów warto przytoczyć badania które wchodzą w polemikę z popularnymi (także w Polsce) stereotypami ${ }^{12}$. Zatem wielu gejów pozostaje w długoterminowych związkach, dzieląc pomiędzy siebie obowiązki tak, jak dzieje się to w parach heteroseksualnych. Jednak w przeciwieństwie do nich, w świetle prawa, są oni obcymi dla siebie osobami. W tym miejscu autorzy podają przykład pojawiający się w dyskursie bardzo często - dotyczący możliwości odwiedzania swojego partnera w szpitalu. Badania z lat 1978 - 1991, których wyniki przytaczają Pope, Wierzalis, Barret i Rankin przeczą także stereotypowi geja jako osoby, która często zmienia swoich partnerów: 40 - 60\% mężczyzn homoseksualnych pozostaje w długoterminowych związkach. Tym, co spaja te związki mogą być podobne doświadczenia, np. zmagania i walka o to, by móc funkcjonować ze swoją innością w społeczeństwie.

Istotne dla niniejszej pracy wydają się nie tylko spostrzeżenia autorów, wiążące się pośrednio z dyskryminacja, ale także specyfiką gejów jako grupy. Geje bowiem, jako członkowie grupy dyskryminowanej, często poszukają tego, co może być dla nich powodem do dumy i źródłem akceptacji. Często fizyczna atrakcyjność i aktywność seksualna są kryteriami, według których oceniają siebie i innych. Od przełomu życia po późną dorosłość muszą zatem konfrontować się z obniżaniem się własnej atrakcyjności: „Większość negatywnych przekonań związanych ze starzeniem się dotyczy ciała.... Geje bardzo inwestują w swoje ciało i wielu czuje, że jest ono ich największym atutem - nie tylko ze względu na seks, ale także dla ich poczucia atrakcyjności, siły i sukcesu"13. Geje przywiązują wielką wagę do swojej fizycznej atrakcyjności, jako ważnego aspektu ich życia. Jednak wiek znacząco tę atrakcyjność obniża - często zmiany, jakie zachodzą w ciele i ich doświadczanie jest bardzo trudne.

\section{INSPIRACJA DLA POLSKICH BADAŃ NAD GENERATYWNOŚCIĄ GEJÓW}

Autorzy w swoim artykule z 1998 r. zauważaja, że niewiele badań naukowych na gruncie psychologii traktuje o osobach homoseksualnych, w tym o gejach, w średnim wieku. Jednak należy zauważyć, że opisują oni amerykańską rzeczywistość. W Polsce publikacji na temat gejów w średnim wieku, podejmujących temat generatywności nie ma. Zatem wszelkich wskazówek do badań, choć po części związanych z generatywnościa, należy szukać m. in. w artykule Cohlera i innych. Autorzy wyraźnie zaznaczają że najważniejsze pytanie w badaniach nad genera-

\footnotetext{
11 D. P. Mc Adams, Sexual lives: The development of traits, adaptations, and stories, “Human Development” 2005, nr 48, s. 298-302.

12 M. Pope, E. A. Wierzalis, B. Barret, M. Rankin, Sexual ..., dz. cyt., s. 72.

13 Tamże, s. 28.
} 
tywnością i orientacją seksualną dotyczy wpływu nietradycyjnej i nienormatywnej trajektorii ich rozwoju. Podobnej wagi są pytania na temat stygmatyzacji i jej wpływu na życiowe doświadczenie. Te dwa czynniki mogą bowiem dawać poczucie bycia innym i przez to prowadzić do innej ekspresji generatywności. Autorzy sugeruja, co jest również istotne w kontekście niniejszej pracy, że dalsze badania nad generatywnością i orientacją seksualną powinny brać pod uwagę również ich związek z procesem starzenia się. Być może wyniki badań okażą się przydatne dla praktyki. Społeczeństwo polskie starzeje się, a 5\% tego społeczeństwa, o czym nie można zapominać, stanowią osoby o orientacji homoseksualnej. W Stanach Zjednoczonych od lat siedemdziesiątych ubiegłego wieku w literaturze naukowej pisano na temat starości i starzenia się gejów. W Polsce temat ten zdaje się być nieobecnym w naukowym dyskursie psychologicznym.

Amerykańskie doniesienia skłoniły mnie do podjęcia badań nad generatywnością gejów po 40. roku życia. Narzędziem wykorzystanym do badań nad generatywnością jest wywiad semistrukturalny, składający się ze skonstruowanych przeze mnie pytań opartych na teorii generatywności Mc Adamsa ${ }^{14}$. Na podstawie dotychczas zebranego materiału jakościowego (sześć narracji) można - z zachowaniem należytej ostrożności - pokrótce opisać, czy raczej zasygnalizować, jak przejawia się generatywność w życiu gejów oraz jakie znaczenie miał dla nich coming - out, a także czy doświadczali dyskryminacji ze względu na orientację.

\section{WSTĘPNE OMÓWIENIE CZĘŚCI WYWIADÓW}

Jeżeli chodzi o pierwszy obszar generatywności (oczekiwania społeczne) badani pytani o to, czy chcą przekazaćjakieś wartości młodemu pokoleniu odpowiadali m.in. że chcieliby, aby młodzi potrafili doceniać własną wartość. Dla jednego z badanych ważne było przekazanie młodym etosu solidnej i ciężkiej pracy, która przynosi efekty. Inny natomiast podkreślał, że ważne jest dla niego to, że może przekazać młodym swoją wiedzę, by nie musieli się uczyć na własnych błędach, ale mogli czerpać z jego doświadczeń.

By przyjrzeć się kolejnemu obszarowi generatywności (wiara w siebie i w ludzkość) pytałam badanych o to, czy akceptują siebie jako gejów oraz czy są akceptowani w swoim środowisku. Pięciu z nich nie ma problemu z akceptacją własnej orientacji seksualnej i rzadko (lub wcale) nie spotkali się z jawną dyskryminacją. Badani pytani o to, czy pomagają dzieciom, które są w ich rodzinie (siostrzeńcy, bratankowie) wyraźnie przejawiają to, co Mc Adams nazywa "generatywnymi troskami". Jeżeli tylko badany utrzymuje kontakt ze swoją rodzina, to stara się wspierać młodsze pokolenie - jeden z badanych mówił wręcz o wsparciu finansowym, którego udziela dzieciom swej siostry.

Kreatywne pragnienia badani ujawnili odpowiadając na pytanie, czy czują się potrzebni (komu?). Najczęściej odpowiedzi dotyczyły przyjaciół oraz osób młodszych, z którymi mają kontakt, np. jeden $\mathrm{z}$ biorących udział $\mathrm{w}$ badaniu jest $\mathrm{w}$ swoim mieście wziętym korepetytorem. Czerpie wielką satysfakcję ze swojej pracy nie tylko wtedy, gdy jego podopieczni zaliczają kartkówki i egzaminy, ale przede wszystkim wtedy, gdy podtrzymują z nim kontakt po zakończeniu nauki lub po latach ",wpadają w odwiedziny do swojego belfra".

Każdy z badanych wyrażał chęć podtrzymania swej dotychczasowej działalności na rzecz młodszego pokolenia (kreatywne zaangażowanie i działania). Jeden z badanych wraz ze swym partnerem rozważa możliwość anonimowego przekazania swojego spadku na rzecz wychowanka domu dziecka, by zapewnić mu tzw. „dobry start”. Inna osoba badana natomiast ma

${ }_{14}$ K. Stęplewska-Żakowicz, K. Kreutz (red.), Wywiad psychologiczny. Wywiad jako postępowanie badawcze, t. 1, Warszawa 2005, s. 39-44. 
poczucie, że wciąż jeszcze ma wiele do przekazania swoim pracownikom (młodym ludziom) i chce ich nauczyć wszystkiego, co sam wie.

Odwołując się do ostatniej kategorii generatywności wg Mc Adamsa (osobista narracja) badani stwierdzaja, że troska i działanie na rzecz młodego pokolenia zajmuje w ich życiu bardzo ważne miejsce. W narracjach wiele miejsca badani poświęcają opisom pomocy, której starają się udzielać młodemu pokoleniu. Poza wymienionymi wyżej przykładami warto odwołać się do relacji innego z badanych, który wspiera swojego siostrzeńca w wychodzeniu z uzależnienia od alkoholu, inny z kolei zatrudnia młodych ludzi w swojej firmie, by mogli zdobyć potrzebne na rynku pracy doświadczenie.

Na podstawie tych fragmentarycznych danych można wnioskować, że rodzicielstwo nie jest koniecznym warunkiem generatywności (tylko jeden z badanych ma dzieci) - może się ona przejawiać także w życiu zawodowym.

W narracjach można także szukać odpowiedzi na pytania stawiane w amerykańskich badaniach omawianych powyżej. Jeżeli chodzi o coming - out, to tylko jeden z badanych go nie dokonał - ukrywa swoją orientację przed żoną i dziećmi, decydując się na tzw. „podwójne życie”. Pozostali badani zdecydowali się na coming - out w młodości. W przypadku jednego z badanych pierwszą osobą, której powiedział o tym, że jest gejem, była mama. Opisywał ją jako wyjątkową, niezwykle ciepłą osobę, która zawsze go wspierała, zaś jego długoletni partner stał się dla niej „drugim synem”. Jednak większość badanych dokonała coming - out'u jedynie w rodzinie i wśród przyjaciół. W pracy nie mówili o swojej orientacji - jedni uważaja, że nie wyobrażają sobie mówienia o tym, co jest ich prywatną sprawa, inni obawiają się, jak taka informacja zostałaby przyjęta. Warto zaznaczyć, że żaden z badanych nie podał żadnego przykładu jawnej dyskryminacji, która by ich dotknęła w jakimkolwiek obszarze życia. Przyczyną tego jest być może właśnie fakt, że o ich orientacji rzadko wie ktokolwiek spoza rodziny lub bliskich przyjaciół.

Co do przekonań na temat ciała i zmian, które w nim zachodzą wydaje się, że większość badanych godzi się z nimi i nie stara się im w jakiś szczególny sposób przeciwdziałać. Osoby, które nie są aktualnie w związkach wyrażają przekonanie, że wraz z upływem czasu coraz trudniej będzie im znaleźć partnera, właśnie ze względu na własną malejącą atrakcyjność fizyczną. Jednak każda z osób nie będących aktualnie w związku bardzo go pragnie, mając na myśli relację trwałą i długoterminowa. Badani samotni chcieliby jeszcze raz, jak deklaruja „ułożyć sobie życie”.

Jedna z rozmów wydała mi się szczególnie interesująca, warta szerszego omówienia w niniejszym opracowaniu - ze wzglądu na szczególnie trudną sytuację badanego. Badany o pseudonimie Joshua5 jest nosicielem wirusa HIV (zakaził go jego poprzedni partner), a także niepijącym alkoholikiem. Te poważne choroby nie hamują jego generatywności - wręcz przeciwnie - wydają się ją wzmacniać. Badany pytany o to, czy jest coś, co chce przekazać młodym ludziom odpowiada o swojej działalności na internetowym portalu Pozytywni.pl, który skupia osoby zakażone wirusem HIV. Rozmawia tam najczęściej z młodymi ludźmi. Na pytanie, czy są wartości, które chciałby przekazać młodym odpowiada następująco: „Tak, ja cały czas to robię, bo mówię im, że są piękni. Jako ludzie. Zauważam ich talenty, jak mają jakieś. Wszystkie błędy im wybaczam. Jest to łatwe, $w$ tym sensie, że mi to łatwo przychodzi, bo system wartości jest przejrzysty - że nie liczy się to, co jest w markecie, to co się błyszczy, tylko to, co jest w środku; że każdy człowiek jest ważny, wyjątkowy, niepowtarzalny; że popełniamy błędy i każdy z nas ma tysiące wad (...); że musimy sobie sami umieć wybaczać wiele rzeczy; że miłość jest ważna, że przyjaźn jest ważna, dotrzymywanie słowa, punktualność, dotrzymywanie zobowiązań; że świat nie jest burdelem, że to jest jednak świat wartości różnych". Powyższy cytat świadczy nie tylko o potrzebie przekazy- 
wania wartości, ale także o wielkiej trosce o młodych ludzi. Joshua5 nie ma kontaktu z rodzina, więc nie ma też możliwości wspierania siostrzenic lub bratanków, jednak wydaje się, że swoją "generatywną troskę" kieruje na młodych ludzi zarejestrowanych na Pozytywnych.pl i stara się ich wspierać, także emocjonalnie: „Jeżeli jakaś nastolatka napisze wiersz, który jest w sumie taki nieporadny, to piszę, że jest piękny, bo świadczy o jej wrażliwości. Nie oceniam tego wiersza, ale odnoszę się do jej wrażliwości. Jest tam taki młody człowiek, który ma stu znajomych, a tylko ze mną konsultuje sprawy (...). Powiem Ci, że czasem mi to pochłania mnóstwo czasu i energii, bo ja nie lekceważę tych osób". Wyraźny jest jednak w wypowiedziach badanego dystans, do tego, co robi - często żartuje, śmieje się sam z siebie. Wielokrotnie wspomina o tym, że czuje się potrzebny, jednak nie ma, jak sam mówi - „poczucia misji”. Zatem można nazwać to realizacją generatywnych pragnień, ale nie za wszelką cenę, z szacunkiem dla autonomii młodych ludzi: „oni muszą być sobie potrzebni, muszą sobie wyrobić własne zdanie, ja nie chcę być żadnym guru, żadnym przewodnikiem (...). Przekazuję ile mogę, ale nie na siłę. Jeżeli jestem pewien, że to, co przekazuję jest mądre (...) mówię, co uważam, mam większe doświadczenie, większe przeżycia. Ja mam inne zdanie od większości ludzi na forum dlatego, że jestem sam. Nikt nie przeżył takiej sytuacji, w której się rodzina odwraca zupełnie bez powodu. Nikt nie poświęcił wszystkich oszczędności na mieszkanie. Po prostu mam inne spojrzenie (...). Albo sytuacja, w której ludzie mają zdanie konkretne, ja mam takie pośrednie (śmiech). Ostatnio się kłócili, że tam na paradzie nagość, a inni mówia, że płytkie wypowiedzi. A ja piszę, że »piszcie nawet o gołych d... nad jeziorem płytkim i tak was lubię». I oni wtedy głupieją. Tak postępuję, żeby przywołać wszystkich do porządku, że nie po to tutaj jesteśmy, żeby na siebie szczekać". Joshua5, pomimo tego, że jego własna sytuacja jest trudna, znajduje czas i energię, by działać na rzecz młodych ludzi. Z jego wypowiedzi można wnioskować, że generatywność jest, ale też zawsze była, istotną częścią jego życia: „Zawsze taki byłem. To jest zgodne z moja naturą. To nie jest tak, że sobie odkryłem Fellow ${ }^{15}$ i Pozytywnych (...). Buduję w ludziach poczucie ich wartości - tych, którzy mają problemy z HIV - wspieram. Tych, którzy nikogo nie chcą - to po dwóch tygodniach już coś myśla, a po trzech już rozmawiają. Tak pracuję z tymi ludźmi, tak pracujemy". Z charakterystyczną dla siebie prostotą i dystansem podsumował naszą rozmowę, odnosząc się do tematu coming - out'u: „W pracy - myślę, że połowa dziewczyn tak uważa. Jak któraś ma jakąś chorobę, to ja załatwiam, ja odwiedzam, ja jeżdżę po szpitalach. Jak mają dzieci, to im jakieś bajki podrzucam, jak mają Komunię, to prezenty. Jak mają facetów, to umiem z nimi narzekać na tych facetów. Ale też je podrywam - wszystkie, bez wyjąt$\mathrm{ku}$ - żeby się czuły doceniane niezależnie od tego, jak wyglądają. To jest ważne. W najgorszym razie się ze mnie śmieją". Zatem dla badanego bycie gejem jest w jakimś sensie równoznaczne z niesieniem pomocy, wspieraniem. W szerszym kontekście - właśnie z generatywnością.

Powyższe rozważania są pewnym zarysem tematyki generatywności wśród gejów. W świetle dotychczasowych wyników można stwierdzić, że badani przeze mnie geje przejawiają generatywność, we wszystkich sferach, które opisuje w swej teorii Mc Adams. W ich życiu są obecne generatywne troski, pragnienia, starają się z zaangażowaniem działać na rzecz młodego pokolenia.

Coraz ważniejszym tematem, jak można sądzić, stanie się - przede wszystkim w wymiarze społecznym - coming - out. Z całą pewnością warto bliżej przyjrzeć się temu zagadnieniu, w świetle wciąż zachodzących w naszym kraju przemian światopoglądowych. Wciąż bowiem, czytając angielskojęzyczną literaturę z zakresu psychologii, chociażby z połowy lat dziewięćdziesiątych, można odnieść wrażenie, że polskiej psychologii zagadnienia związane z mniejszościami sek-

15 Gejowski portal randkowy. 
sualnymi nie dotyczą (nie interesują?). Moim zdaniem badacze powinni z uwagą przyjrzeć się także zagadnieniu dyskryminacji. Zjawisko to, dobrze opisane na gruncie nauk społecznych, ma także swój wymiar jednostkowy. Z pewnością coming - out nie byłyby dla gejów tak wielkim wyzwaniem, gdyby nie obawiali się odrzucenia, napiętnowania, a tym samym przejawów dyskryminacji. Zatem opisanie doświadczenia dyskryminacji oraz jej antycypowania przez gejów, czy też mniejszości seksualne w ogóle, zdaje się być zagadnieniem interesującym. Być może te sugestie dotyczące dalszych kierunków badań staną się inspiracją dla innych (przyszłych) psychologów i ważny społecznie temat uzyska swoje (należne mu) miejsce w polskim dyskursie psychologicznym.

\section{BibLIOGRAFIA}

Cohler B., Hostetler A. J., Boxer A. M., Generativity, social context, and lived experience: Narratives of gay men in middle adulthood, [w:] Mc Adams D. P., de St. Aubin E. (red.), Generativity and adult development: How and why we care for the next generation, Washington 1998.

Lachman M. E. (red.), Handbook of midlife development, New York 2001.

Mc Adams D. P., Generativity in midlife, [w:] Lachman M. E. (red.), Handbook of midlife development, New York 2001.

Mc Adams D. P., Sexual lives: The development of traits, adaptations, and stories, "Human Development" 2005, nr 48, s. $298-302$.

Mc Adams D. P., de St. Aubin, A theory of generativity and its assessment through self-report, behavioral acts, and narrative themes in autobiography, "Journal of Personality and Social Psychology" 1992, nr 62, s. 1003-1015.

Mc Adams D. P., de St. Aubin, Logan R., Generativity among young, midlife and older adults, "Psychology and Aging" 1993, nr 8, s. 221-230.

Mc Adams D. P., de St. Aubin E. (red.), Generativity and adult development: How and why we care for the next generation, Washington 1998.

Pope M., Wierzalis E. A., Barret B., Rankin M., Sexual and intimacy issues for aging gay men, "Adultspan Jurnal" 2007, nr 6, s. 68-82.

Stęplewska-Żakowicz K., Kreutz K. (red.), Wywiad psychologiczny. Wywiad jako postępowanie badawcze, t. 1, Warszawa 2005. Oleś P. K., Psychologia przełomu połowy życia, Lublin 2000.

Oleś P. K., Wprowadzenie do psychologii osobowości, Warszawa 2008.

\section{Słowa kluczowe}

generatywność, geje, coming - out, dyskryminacja ze względu na orientację seksualną

\section{STReszczenie}

Celem pracy jest przybliżenie amerykańskich badań dotyczących generatywności wśród gejów jako inspiracji do badań własnych autorki (analiza narracji gejów). Punktem wyjścia jest prezentacja teorii generatywności amerykańskiego psychologa D. Mc Adamsa, która jest twórczym rozwinięciem myśli E. Eriksona. Generatywność przejawia się w ciagu całego życia jednostki, jednak jej znaczenie rośnie po 40. roku życia, zwanym niekiedy okresem „przełomu” bądź „kryzysu”. Najogólniej generatywność wiązana jest z chęcią wspierania przyszłych pokoleń, najczęściej zaś z rodzicielstwem. Amerykańscy badacze , m.in. Hostetler i Boxer zwracają jednak uwagę na to, że nie można generatywności ograniczać wyłącznie do rodzicielstwa, czego dowody znajdują w badaniach prowadzonych wśród gejów. Czynniki mogące wpływać na ekspresję generatywności to m.in. coming out oraz doświadczanie dyskryminacji ze względu na orientację seksualną. Wnioski z badań amerykańskich stały się dla autorki niniejszej pracy inspiracją do postawienia pytań o przejawy generatywności polskich gejów i możliwości jej badania. 


\section{GENERATIVITY OF GAYS AFTER TURNING FOURTY}

\section{- AMerican insPiration for POlish Research}

\section{Keywords}

Generativity, gays, coming-out, sexual orientation discrimination

\section{Summary}

The aim of this article is to present American research on generativity among gays as an inspiration for the author's own research (analysis of gays' narrations). The starting point is a presentation of generativity theory stated by American psychologist D. McAdams which is a creative development of E. Erikson's ideas. Generativity manifests throughout the whole life of a human being, but its role increases significantly after turning fourty. This period is sometimes called a period of "breakthrough" or "crisis". Generally, generativity is linked to the willingness to support succeeding generations, and most often - to parenthood. According to American scientists, among others Hostetler and Boxer, generativity cannot be limited merely to parenthood. They claim that proofs of this theory can be found in research conducted among gays. Among factors which might affect expression of generativity they enumerate coming-out and experiencing discrimination connected to sexual orientation. For the author of this article, conclusions of the American research became the inspiration to ask a few questions about signs of Polish gays' generativity and chances to research it. 